Syntax Idea: p-ISSN: 2684-6853 e-ISSN: 2684-883X

Vol. 3, No. 12, Desember 2021

\title{
PENCITRAAN KEDOKTERAN NUKLIR PADA PASIEN METASTASIS TULANG DENGAN KANKER PAYUDARA
}

\author{
Esther Devina Panjaitan, Hendra Budiawan \\ Universitas Padjajaran (UNPAD) Bandung, JawaBarat, Indonesia \\ Email:dvn_b@yahoo.com, stherdevina@gmail.com
}

\begin{abstract}
Abstrak
Tulang adalah tempat paling umum di mana kanker payudara bermetastasis dan kadang-kadang merupakan tempat pertama yang terkena dampak pada sebagian besar wanita dengan kanker payudara stadium lanjut. Banyak penelitian telah menyoroti bahwa modalitas pencitraan memvisualisasikan berbagai aspek jaringan tulang (korteks atau sumsum). Pencitraan metastasis tulang bermasalah karena lesi dapat berupa osteolitik, osteoblastik, atau campuran, dan modalitas pencitraan didasarkan pada visualisasi anatomis langsung dari tulang atau tumor atau pengukuran tidak langsung dari metabolisme tulang atau tumor. Pencitraan tulang dengan skintigrafi skeletal dapat menjadi bagian penting, dan tomografi emisi positron atau tomografi terkomputasi emisi foton tunggal memiliki potensi untuk mengevaluasi metastasis tulang, tetapi tidak ada konsensus mengenai modalitas terbaik untuk mendiagnosis lesi dan untuk menilai responsnya terhadap pengobatan. Dalam ulasan ini, kami membahas penggunaan masing-masing pencitraan nuklir untuk modalitas tulang untuk mendiagnosis metastasis tulang dari kanker payudara.
\end{abstract}

Kata Kunci: Sidik tulang; metastasis tulang; kanker payudara; FDG-PET

\section{Abstract}

Bone is the most common site to which breast cancer metastasizes and sometimes is the first affected site in a substantial proportion of women with advanced breast cancer. A lot of study has highlighted that imaging modalities visualize different aspects of osseous tissues (cortex or marrow). Imaging bone metastases is problematic because the lesions can be osteolytic, osteoblastic, or mixed, and imaging modalities are based on either direct anatomic visualization of the bone or tumor or indirect measurements of bone or tumor metabolism. Bone imaging by skeletal scintigraphy can be an essential part, and positron emission tomography or single-photon emission computed tomography have a potential of evaluating bone metastases, but no consensus exists as to the best modality for diagnosing the lesion and for assessing its response to treatment. In this review, we discuss the use of each nuclear imaging for bone modality for diagnosing bone metastases from breast cancer.

Keywords: Bone scan; bone metastases; breast cancer; FDG-PET

Received: 2021-11-22; Accepted: 2021-12-05; Published: 2021-12-20

$\begin{array}{ll}\text { How to cite: } & \text { E, D Panjaitan., \& Budiawan, H, (2021) Pencitraan Kedokteran Nuklir Pada Pasien Metastasis } \\ & \text { Tulang dengan Kanker Payudara, Syntax Idea, 3(12), https://doi.org/10.36418/syntax- } \\ & \text { ideav3i11.1542 }\end{array}$




\section{Pendahuluan}

Kanker payudara merupakan salah satu masalah utama kesehatan wanita di dunia. Data Globocan menyebutkan di tahun 2018 terdapat 18,1 juta kasus baru dengan kanker paru menduduki peringkat pertama (baik pada laki-laki dan perempuan) diikuti kanker payudara (pada perempuan), kanker prostat (pada laki-laki) dan kanker colorectal (Bray et al., 2018). Di negara maju seperti Amerika Serikat dan Kanada, sekitar 70\% kasus baru diketahui secara histopatologis pada kanker payudara stadium awal, sedangkan di negara berkembang seperti Asia Tenggara, kebanyakan kanker payudara terdiagnosis pada stadium III atau IV (Jamnasi et al., 2016). Angka kejadian penyakit kanker di Indonesia (136.2/100.000 penduduk) berada pada urutan 8 di Asia Tenggara, sedangkan di Asia urutan ke 23. Angka kejadian tertinggi di Indonesia untuk perempuan yang tertinggi adalah kanker payudara yaitu sebesar 42,1 per 100.000 penduduk dengan ratarata kematian 17 per 100.000 penduduk (Kemenkes, 2019).

Penyebab utama kematian yang tersering pada kanker payudara adalah metastasis jauh. Tulang adalah tempat yang paling umum dari metastasis jauh kanker payudara serta merupakan tempat pertama terkena dalam sebagian besar perempuan dengan kanker payudara stadium lanjut. Metastatik tulang umumnya ditemukan dalam pola lesi yang multiple, namun demikian lesi tulang tunggal juga dapat mewakili suatu metastasis tulang (Kozlow \& Guise, 2005). Semakin banyak lokasi metastasis yang terlibat, semakin buruk dengan prognosis dan kualitas hidup pasien.

Pencitraan memiliki peranan penting dalam mendeteksi metastasis, menentukan prognosis, merencanakan pengobatan dan memonitor metastasis tulang. Pada pasien yang tidak diketahui mengalami keganasan, diagnosis metastasis tulang dapat dibuat dengan adanya temuan radiografi dan pencitraan lainnya (Hamaoka, Madewell, Podoloff, Hortobagyi, \& Ueno, 2004). Jika terdapat metastasis tulang atau dicurigai, pencitraan lebih lanjut ataupun teknik yang dipandu dengan pencitraan dibutuhkan untuk mengkonfirmasi diagnosis dan untuk mengetahui tumor primernya (Costelloe et al., 2009). Saat ditemukan metastasis tulang sering sudah dalam jumlah yang banyak.

Pada orang dewasa lesi secara umum terdapat pada tulang aksial dan tempat lain dengan residu sumsum tulang merah. Lebih dari $90 \%$ metastasis tulang bertempat di vertebra, pelvis, bagian proksimal femur dan bagian proksimal dari humerus (Kozlow \& Guise, 2005). Pada penelitian lain ditemukan bahwa metastasis tulang pada kanker payudara terbanyak dijumpai di sternum. Adakalanya pasien dengan metastasis tulang datang dengan keluhan fraktur patologis; oleh karena itu penting untuk memeriksa bagian tulang tersebut apabila dicurigai adanya fraktur. Disamping itu, pasien dapat datang dengan komplikasi dari metastasis tulang, seperti gangguan neurologis akibat penekanan pada epidural spinal (Hilton et al., 2011). Memahami jalur penyebaran kanker ke tulang mungkin dapat membantu dalam mendeteksi metastasis tulang tunggal.

Pencitraan tulang telah menjadi bagian terbesar kedua dalam prosedur pencitraan nuklir, menawarkan keuntungan pemeriksaan tubuh keseluruhan, biaya rendah dan sensitivitas tinggi. Kekuatannya terletak pada uptake fisiologis dan patofisiologis dari 
radiofarmaka yang digunakan. Utilitas, sensitivitas, spesifitas dan nilai prediksi diagnostik pencitraan tulang untuk kondisi jinak dan tumor berbeda pada setiap modalitas.

\section{Metode Penelitian}

Penelitian ini merupakan penelitian dengan menggunakan metode studi kepustakaan atau literature review. Jenis literature review yang digunakan adalah metode narrative review. Kami mencari artikel yang relevan dengan materi dari Pubmed dengan artikel berbahasa inggris. Kami menggunakan kata kunci seperti: bone metastases, breast cancer, bone imaging, bone scan. Kami melakukan inklusi artikel dan review artikel, kemudian mengeksklusi artikel yang tidak berhubungan.

Semua artikel dianalisis untuk didiskusikan mengenai materi-materi mengenai metastasis tulang pada kanker payudara dan pencitraan nuklir yang digunakan untuk mendeteksi metastasis tulang serta algoritme pemeriksaan pada metastasis tulang.

\section{Hasil dan Pembahasan}

\section{A. Hasil Penelitian}

Berdasarkan kriteria inklusi dan eksklusi tersebut kami mendapatkan 20 artikel yang berkaitan dengan pencitraan nuklir pada metastasis tulang pasien kanker payudara. Artikel tersebut dapat berupa penelitian, systematic review maupun casereport. Tempat dilakukan penelitian dari artikel tersebut semua berasal dari luar negeri, di benua Asia, Eropa, dan Amerika.

\section{B. Pembahasan}

\section{Patofisiologi metastasis tulang}

Mekanisme molekuler metastasis tulang kanker payudara adalah yang paling penting, namun belum sepenuhnya dapat dipenuhi. Lebih dari satu abad yang lalu, Stephen Paget mengusulkan teori "seed and soil" (teori biji dan tanah), bahwa sel-sel tumor adalah biji dan lingkungan mikro tulang adalah tanah. Lingkungan mikro jaringan tulang dapat berfungsi sebagai tanah subur di mana sel-sel kanker dapat tumbuh (Kozlow \& Guise, 2005). Gagasan ini telah diterima secara luas sejak saat itu dan tetap menjadi dasar prinsip di bidang metastasis kanker bahkan hingga saat ini. Mekanisme regulasi "seed and soil" pada metastasis kanker payudara dapat dilihat pada gambar 1 .

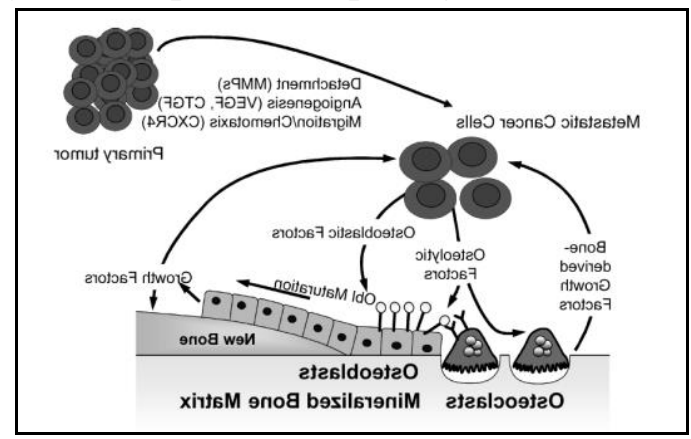

Gambar 1

Mekanisme hipotesis seed and soil 
Tulang merupakan sumber dihasilkannya faktor-faktor pertumbuhan (transforming growth factor $\beta$, insulin like growth factors I dan II, fibroblast growth factor, platelet derived growth factors, bone morphogenic protein dan kalsium). Faktor-faktor ini dihasilkan dan teraktivasi pada proses resorpsi tulang dan merupakan "tanah yang subur" untuk pertumbuhan sel kanker (seed and soil hypothesis) (Kozlow \& Guise, 2005).

Homing hypothesis menyatakan bahwa metastasis tulang pada kanker payudara disebabkan oleh sel-sel tumor spesifik untuk tulang, tipe sel tumor spesifik ini bermetastasis pada organ yang berbeda dipengaruhi oleh kemokin. Meskipun kedua hipotesis ini telah diterima secara luas, namun masih ada beberapa faktor lain yang mempengaruhi metastasis tulang (Zhong, Wu, Zhu, \& Lin, 2015). Proses metastasis tulang kanker payudara sangat kompleks dan saling terkait dengan banyak sitokin, faktor pertumbuhan dan jalur sinyal molekuler (Roodman, 2004).

Metastasis tulang terjadi melalui 3 mekanisme, yaitu: (1) perluasan secara langsung; (2) aliran vena retrograde; dan (3) penyebaran emboli tumor melalui sirkulasi darah. Awalnya penyebaran metastasis terjadi pada sumsum tulang. Beberapa faktor berperan dalam terjadinya metastasis kanker ke tulang yaitu (Kozlow \& Guise, 2005):

2. Aliran darah yang banyak pada sumsum tulang.

Sel kanker menghasilkan molekul adhesi yang menyebabkan menempelnya sel kanker pada sel stroma sumsum tulang dan matriks tulang. Adanya proses adhesi ini menyebabkan meningkatnya produksi faktor-faktor angiogenik dan faktor-faktor resorpsi tulang yang akan meningkatkan pertumbuhan kanker ditulang. Faktor-faktor tersebut antara lain:

a. Ekspresi reseptor kemokin CXCR4 pada sel kanker yang akan berikatan dengan stromal cell-derived factor 1 (SDF-1 disebut juga CXCL 12) pada tulang.

b. Ekspresi receptor activator of nuclear factor kappa $\beta$ ligand (RANKL) pada tulang berperan dalam metastasis tulang melalui ikatan pada reseptor activator of nuclear factor kappa $\beta$ pada permukaan sel kanker.

Lesi metastasis tumbuh dirongga medula, tulang disekitarnya akan berubah bentuk baik melalui proses osteoklas maupun osteoblas. Derajat resultan dari resorpsi atau deposisi pada tulang yang mengalami metastasis tergantung pada jenis dan lokasi tumor. Metastasis tulang dapat terdiri dari lesi osteolitik dan osteoblastik. Pada seorang penderita kanker dapat ditemukan beberapa lesi metastasis tulang osteolitik dan osteoblastik atau lesi tulang berupa campuran osteolitik dan osteoblastik. Sebagian besar penderita kanker payudara mempunyai lesi tulang prodominan berupa osteolitik. Meskipun demikian sekitar 15-20\% penderita mempunyai lesi tulang predominan osteoblastik (Zhong et al., 2015).

Menurut penelitian Roodman pada tahun 2004, sel kanker payudara menghasilkan faktor-faktor yang secara langsung dan tidak langsung dapat 
menginduksi pembentukan osteoklas. Sebaliknya dalam proses resorpsi tulang oleh osteoklast akan dihasilkan faktor-faktor pertumbuhan dari matriks tulang yang akan merangsang sel tumor dan kerusakan tulang. Interaksi timbal balik antara sel kanker payudara dan lingkungan mikro tulang akan meningkatkan kerusakan pada tulang dan pertumbuhan sel kanker. Bentuk patologis yang lain yaitu lesi osteoblastik, dimana sel kanker merangsang osteoblas untuk bekerja lebih keras sehingga terjadi pertumbuhan tulang yang abnormal. Keduanya menyebabkan tulang menjadi rapuh dan mudah mengalami fraktur (Roodman, 2004). Proses tersebut dapat dilihat pada gambar 2.

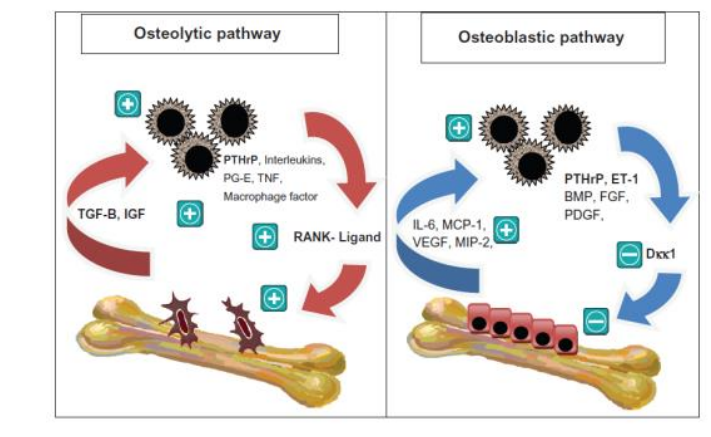

\section{Gambar 2 \\ Mekanisme lesi osteoblastik dan osteolitik}

Sel tumor, terutama kanker payudara menghasilkan parathyroid hormonerelated peptide (PTHrP) yang berperan sebagai stimulator utama pembentukan osteoklas. Sel kanker juga menghasilkan faktor-faktor lain yang meningkatkan pembentukan osteoklas yaitu interleukin-6, prostaglandin E2 (PGE2), tumor necrosis factor dan macrophage colony stimulating factor (M-CSF). Faktor-faktor ini akan meningkatkan ekspresi receptor activator of nuclear factor $\beta$ ligand (RANKL) yang akan bekerja langsung pada prekursor osteoklas untuk menginduksi pembentukan osteoklas dan resorpsi tulang. Proses resorpsi tulang akan menghasilkan transforming growth factor $\beta$ (TGF- $\beta$ ), insulin like growth factors (IGFs), platelet-derived growth factor (PDGF) dan bone morphogenetic proteins (BMPs) yang akan meningkatkan pertumbuhan sel kanker (Zhong et al., 2015). Hubungan timbal balik antara destruksi tulang dan pertumbuhan sel kanker selanjutnya akan meningkatkan destruksi tulang dan pertumbuhan sel kanker (Pulido et al., 2017).

Konsekuensi klinis lain dari metastasis tulang selain fraktur patologis, adalah hiperkalsemia dan kompresi saraf. Supresi pada sumsum tulang dan leukopenia dapat terjadi dengan beban tumor yang cukup dalam tulang. Hiperkalsemia disebabkan oleh kerusakan tulang sebelumnya yang berlebihan, hal ini terjadi pada hingga 30\% pasien kanker payudara dengan keterlibatan tulang. Kaheksia mungkin merupakan konsekuensi klinis tambahan dari metastasis tulang. Banyak pasien kanker dengan stadium terminal menderita kahexia, yang menyebabkan kehilangan massa otot dan massa lemak (Pulido et al., 2017). 
Setelah kanker payudara menyebar di tulang, maka tidak dapat disembuhkan. Namun, perkemabangannya masih relatif lamban, dengan median survival rate (kelangsungan hidup) 2 dan 5 tahun adalah sebesar $40 \%$ pada pasien yang menderita kanker payudara (Zhong et al., 2015).

\section{Imunohistokimia pada kanker payudara}

Pemeriksaan profil imunohistokimia telah digunakan secara luas sebagai dasar dalam pemilihan terapi hormonal dan targeting terapi. Pemeriksaan imunohistokimia dapat mendeteksi jenis reseptor hormon sel kanker, yaitu reseptor estrogen (ER) dan reseptor progesteron (PR), serta ekspresi dari human epidermal growth factor receptor-2 (HER-2). Reseptor hormon ini dapat ditemukan baik pada sel normal maupun sel kanker dan memiliki peran dalam pertumbuhan sel apabila berikatan dengan hormon (Jamnasi et al., 2016).

Penggolongan subtipe kanker payudara berdasarkan pemeriksaan Immunohistochimie (IHC) (Nadji, Gomez-Fernandez, Ganjei-Azar, \& Morales, 2005), yaitu:

- Luminal A: ER/PR (+), HER-2 (-), Ki67 < 25\%.

- Luminal B (HER-2 (-)): ER/PR (+), Ki67 > 25\%.

- Luminal B (HER-2 (+)): ER/PR (+), HER (+), any Ki67.

- HER-2: ER/PR (-), HER-2 (+).

- TNBC (triple negative basal carcinoma): ER/PR (-), HER-2 (-)

Ini adalah subtipe yang paling sering ditemukan tetapi tidak semua tumor akan mempunyai gambaran seperti tersebut di atas. Adakalanya kanker payudara tidak dapat digolongkan seperti itu tetapi termasuk dalam penggolongan lainnya yaitu (Dunnwald, Rossing, \& Li, 2007):

- Luminal ER-/AR+: (overlapping dengan apokrin dan disebut opokrin molekuler)

- teridentifikasi sebagai subtipe androgen responsif yang akan memberikan respon terhadap pemberian terapi antihormonal dengan bicalutamide

- Claudin-low: tipe yang lebih jarang; sering triple-negative, tetapi dibedakan dengan adanya ekspresi yang rendah dari sel - sel protein penghubung termasuk E-cadherin dan sering disertai infiltrasi limfosit.

\section{Pencitraan Nuklir}

\section{1) Sidik Tulang}

Sidik tulang adalah pemeriksaan yang paling umum digunakan dan efektif untuk menskrining seluruh tubuh dalam mendeteksi metastasis tulang; dapat menvisualisasikan peningkatan aktivitas osteoblastik dan vaskularisasi pada tulang (Houssami \& Costelloe, 2012). Sidik tulang pada planar mendeteksi deposit metastatik pada tulang dengan mendeteksi peningkatan aktivitas osteoblastik yang diinduksi sel metastasis; temuan ini dianggap sebagai penanda langsung dari tumor. Indikasi untuk sidik tulang meliputi staging pada pasien asimptomatik, mengevaluasi nyeri persisten dengan adanya temuan radiografi samar-samar atau negative dan telah disarankan sebagai 
yang pertama studi pencitraan pada pasien tanpa gejala (Houssami \& Costelloe, 2012).

Banyak radiofarmaka (radionuklida) yang telah digunakan dalam sidik tulang, termasuk technetium-99m yang dilabel dengan methylene diphosphonate (MDP), hydroxymethylene diphosphonate (HMDP) dan dicarboxypropane diphosphonate (DPD) (Cook, Azad, \& Goh, 2016). Sensitivitas dan tingkat spesifisitas sidik tulang yang dipublikasikan untuk mendiagnosis metastasis tulang sangatlah bervariasi, dengan sensitivitas mulai dari $62 \%$ hingga $100 \%$ dan spesifisitas dari $78 \%$ hingga $100 \%$ (evidence level II dan III). Meskipun sidik tulang pada umumnya dianggap sensitif untuk mendeteksi metastasis osteoblastik ataupun osteolitik pada gambar seluruh tubuh dan lebih sensitive daripada X-ray, sidik tulang dilaporkan memiliki spesifisitas lebih rendah dan tingkat false-positif yang lebih tinggi daripada XRay. Hal ini dikarenakan temuan pada sidik tulang mencerminkan reaksi metabolisme tulang yang dapat terjadi pada beberapa proses penyakit, termasuk neoplasia, trauma, atau inflamasi. Dengan demikian, sidik tulang memiliki kekhususan terbatas dan temuan yang ada perlu dikorelasikan dengan studi pencitraan lebih lanjut (Hamaoka et al., 2004).

Temuan negatif palsu kadang-kadang dapat terjadi ketika dijumpai metastasis osteolitik murni tumbuh dengan cepat, sedangkan pergantian tulang lambat, atau ketika daerah tersebut avaskular (lesi defisiensi-foton; "coldlession"). Walau terkadang lesi osteolitik disertai dengan formasi sekunder dari tulang, yang sangat memungkinkan dideteksi dengan sidik tulang beberapa bulan sebelum mereka muncul di radiografi polos (Li et al., 2015). Meskipun kegunaan sidik tulang dalam mendiagnosis lesi yang luas dan multifocal sangat efektif, namun ketika menghasilkan temuan samar-samar hal tersebut tidak bisa dianggap sebagai diagnostik (misalnya, lesi "mencurigakan" atau satu "hot spot”) (Ju, Yurter, Gokaslan, \& Sciubba, 2014).

Tidak jarang metastasis tulang awalnya muncul sebagai lesi tunggal, beberapa penelitian sebelumnya melaporkan sekitar 7-8\% pasien kanker. Tempat yang paling umum ditemukan adalah tulang aksial (termasuk tulang rusuk, sternum, klavikula) seperti yang ditemukan oleh sidik tulang planar (Lien, Wen, Huang, \& Wu, 2015) yang terlihat pada gambar 3 dimana dijumpai adanya lesi metastasis tulang pada os thorakal VII. 

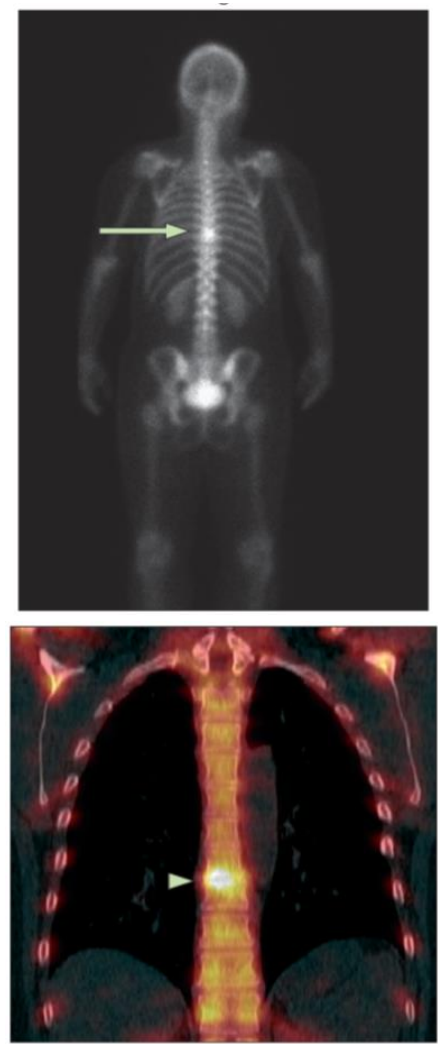

Gambar 3

Sidik tulang planar (gambar atas) dan SPECT/CT (gambar bawah). Tampak single hot-spot pada os.torakal VII

Modalitas pencitraan lain seperti X-Ray, CT, atau MRI harus digunakan untuk mengkarakterisasi lesi tersebut, termasuk komponen jaringan lunak, dan untuk menilai risiko terjadinya fraktur. Sidik tulang juga harus ditambah dengan gambar yang diperoleh dengan modalitas lain untuk memberikan dasar yang valid untuk penilaian respon penanganan metastasis tulang. Konfirmasi histologis juga mungkin diperlukan untuk diagnosis akhir lesi yang mencurigakan. Keuntungan dari sidik tulang bukan untuk diagnosis tetapi untuk skrining dan dapat menghasilkan gambar seluruh tubuh yang cepat dengan biaya yang lebih terjangkau (Cook et al., 2016).

Interval yang tepat antara skrining untuk metastasis tulang, dan frekuensi pemeriksaan ulang kapan harus dilakukakan, belum ditetapkan secara pasti. Evidence level II menunjukkan bahwa tingkat dimana metastasis tulang terdeteksi oleh sidik tulang diantara pasien dengan nodul positive kanker payudara adalah $2,4 \%$. Dalam studi yang sama, tingkat dimana temuan tentang sidik tulang berubah dari negatif pada pencitraan menjadi positif selama 2 tahun ke depan adalah $1,1 \%$ untuk pasien dengan kanker payudara $\mathrm{T} 1$ dan $1,2 \%$ untuk mereka dengan NO. Kombinasi temuan level II dan level III menunjukkan bahwa tingkat deteksi metastasis tulang oleh sidik tulang adalah $0,82 \%$ untuk pasien dengan kanker payudara stadium I, 2,55\% untuk mereka dengan kanker payudara stadium II, 16,75\% untuk stadium III, dan 40,52\% 
untuk pasien dengan kanker payudara stadium IV (Houssami \& Costelloe, 2012).

Dua studi retrospektif menunjukkan bahwa awal deteksi kelainan atau metastasis tulang asimptomatik oleh sidik tulang menghasilkan peningkatan $14 \%$ dalam kelangsungan hidup secara keseluruhan pada 4 tahun pertama dan peningkatan $10 \%$ pada 5 tahun (evidence level III) (Hamaoka et al., 2004). Namun, evidence level III lainnya menunjukkan deteksi dini kekambuhan kanker payudara asimptomatik di studi mana pun (yang tidak terbatas pada tulang tetapi juga organ lain) tidak mempengaruhi tingkat kelangsungan hidup keseluruhan. Selanjutnya, American Society of Pedoman Onkologi Klinis tidak merekomendasikan penggunaan sidik tulang untuk surveilans pasca perawatan dari penyakit yang asimptomatik (Cook et al., 2016).

\section{SPECT/CT}

SPECT menggunakan penanda radionuklida yang sama seperti halnya dengan sidik tulang. SPECT memperoleh gambar dalam sebuah citra crosssectional bukan dalam bentuk citra planar dan menunjukkan sensitivitas dan spesifisitas yang lebih tinggi untuk mendeteksi metastasis tulang belakang; sensitivitasnya untuk diagnosis metastasis tulang adalah $87 \%$ hingga $92 \%$, dan spesifisitasnya adalah 91\% hingga 93\% (evidence level II - III). Selain itu, SPECT dapat membedakan tumor dari lesi inflamasi dan infeksi, tidak seperti sidik tulang planar. Teknologi modern sekarang memungkinkan SPECT dan CT kualitas diagnostik dalam satu alat dan menyatukan gambar SPECT-CT kedalam gambar dilakukan pada mesin yang sama dalam hitungan menit, sehingga meningkatkan akurasi diagnostik dari modalitas tersebut (Minamimoto et al., 2015).

SPECT bermanfaat dalam mengevaluasi daerah kompleks yang banyak dikelilingi oleh jaringan lunak seperti tulang belakang torakolumbalis dan panggul. Untuk pencitraan tulang belakang, penggunaan SPECT dapat untuk mengevaluasi "hot spot" yang ditemukan oleh sidik tulang dan memiliki nilai prediksi negatif sebesar 98\%, yang membuat SPECT berguna dalam membedakan lesi jinak dan ganas seperti yang terlihat pada gambar 4. Meskipun sangat sedikit informasi yang tersedia tentang penggunaan SPECT dalam skrining rutin, namun SPECT telah digunakan untuk membantu diagnosis dalam kasus yang meragukan setelah diskrining dengan sidik tulang planar. Dalam beberapa litertatur dikatakan bahwa penggunaan SPECT lebih sensitif dalam menilai respon terapi pada metastasis tulang (Cook et al., 2016). 

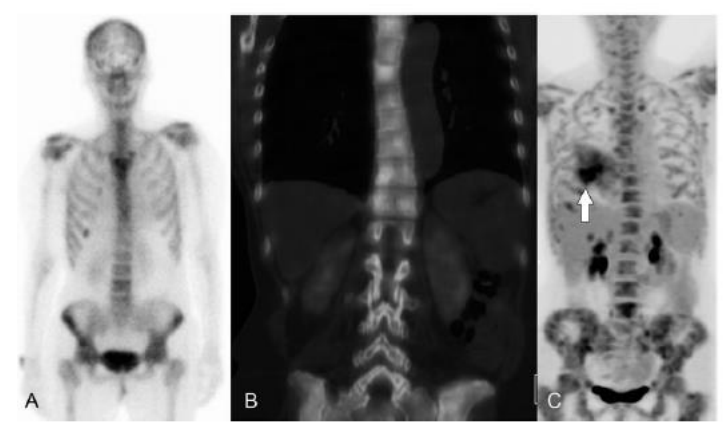

Gambar 4

(A) Sidik tulang planar; (B) SPECT-CT; (C) 18FDG-PET. Staging awal pada pasien berusia 60 tahun dengan kanker payudara dan metastasis tulang

\section{ET/CT}

PET adalah teknik kedokteran nuklir yang menghasilkan gambar tomografi beresolusi tinggi melalui pendeteksian pasangan foton berenergi tinggi yang dipancarkan selama peluruhan positron radioisotop. Untuk metastasis tulang, ada beberapa radiofarmaka yang biasanya digunakan yaitu: 18F-fluoride, pelacak tulang yang tidak spesifik, atau 2-deoxy-2- [18F] fluoro-Dglucose (18FDG), analog glukosa untuk pelacak tumor (Minamimoto et al., 2015).

18FDG-PET adalah metode pencitraan fungsional yang mendeteksi metabolisme sel dari analog glukosa. Karsinoma payudara sering menunjukkan adanya peningkatan moderat dalam metabolisme glukosa dibandingkan jenis tumor lainnya (misalnya, kanker paru-paru). Namun, evidence level II-III, menunjukkan bahwa sensitivitas PET cukup tinggi untuk mengidentifikasi lesi primer pada payudara yang tersembunyi (67\% hingga 100\%), untuk mendeteksi keterlibatan kelenjar getah bening aksila (50\% hingga 100\%), dan untuk mendeteksi metastasis di tulang dan jaringan lainnya (84\% hingga 100\%). Kerugian PET adalah membutuhkan biaya yang lebih tinggi, tidak tersedia disemua tempat (terbatas), dan waktu tambahan yang diperlukan untuk memindai lebih lama dari modalitas pencitraan lain (Hamaoka et al., 2004).

Pada populasi kanker payudara, Boxer et al. menemukan $21 \%$ populasi memiliki metastasis tulang yang bermanifestasi sebagai lesi tunggal pada skintigrafi tulang. Koizumo et al menemukan tingkat kejadian yang lebih tinggi dari $41 \%$ yang disarankan terkait dengan strategi tindak lanjut yang sering, peningkatan peralatan kamera gamma dan teknik pemindaian, dan penggunaan modalitas pencitraan lainnya untuk konfirmasi. Meskipun sebagian besar lesi metastasis tunggal didasarkan pada temuan FDG-PET / CT, temuan serupa diamati dalam penelitian yang dilakukan oleh Hendra B et al ; 40,3\% (27 dari 67 pasien) ditemukan memiliki lesi metastasis tulang tunggal. Temuan serupa ini mungkin karena akurasi yang sama antara skintigrafi tulang dan FDG-PET / CT dalam mendeteksi metastasis tulang (contoh pada gambar 5, 6, 7 dan 8). 


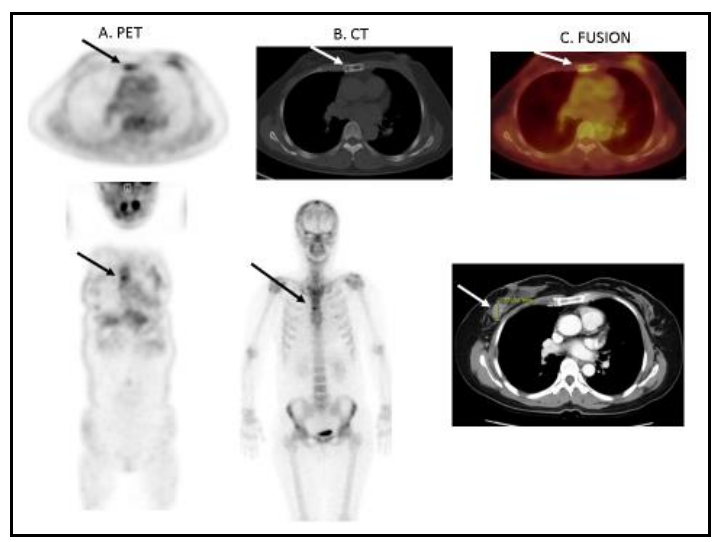

Gambar 5

Lesi tunggal pada sternum yang disebabkan metastasis tulang pada kanker payudara

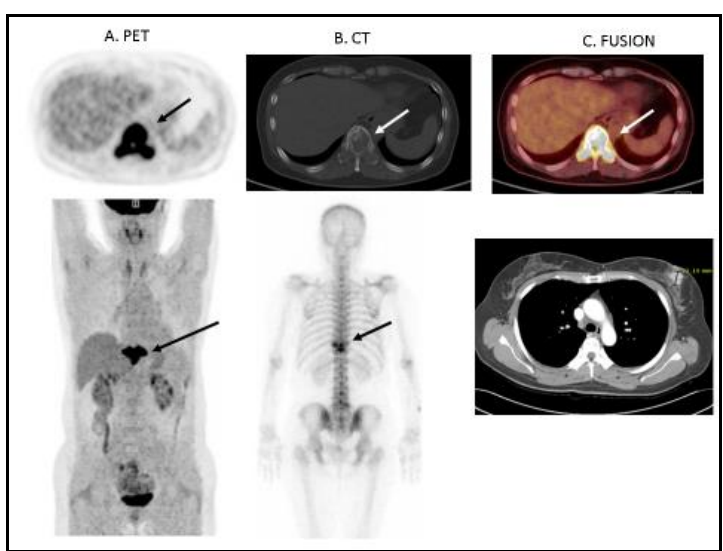

Gambar 6

Lesi metastasis pada os thorakal $\mathrm{X}$, pasien kanker payudara

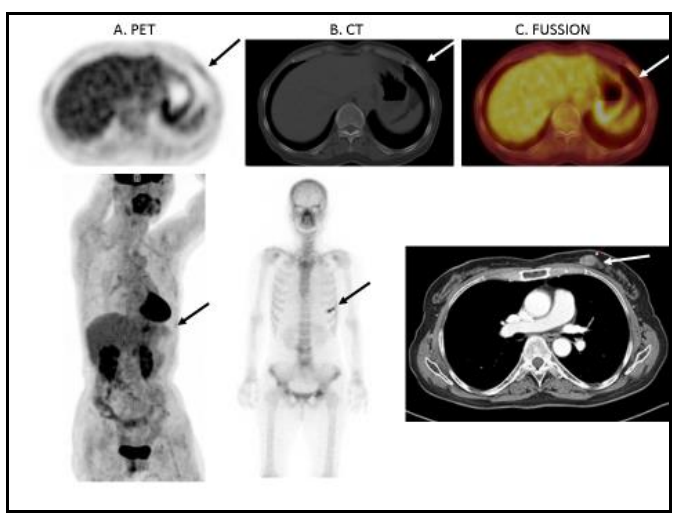

Gambar 7

Lesi metastasis pada costae IX kiri pada metastasis payudara 


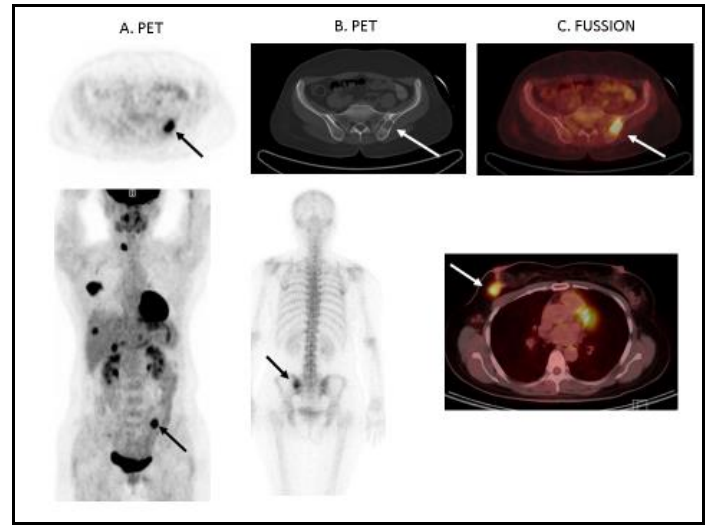

Gambar 8

Lesi metastasis pada pelvis kiri pada pasien dengan kanker payudara

Mekanisme uptake pada 18F-fluoride mirip dengan 99mTc-metilen difosfonat (MDP), tracer yang digunakan dalam sidik tulang; akumulasinya tergantung pada aktivitas osteoblastik dan aliran darah sekitar. 18F-fluoride PET, menunjukkan hasil yang lebih unggul dari pada sidik tulang dalam mendeteksi lesi tulang jinak dan ganas dalam sebuah studi prospektif dari 44 pasien, berpotensi mengantikan sidik tulang atau SPECT untuk pencitraan tulang, namun biaya yang tinggi tetap menjadi perhatian (Parkes et al., 2018).

18FDG-PET telah digunakan untuk mengukur metabolisme glukosa dalam berbagai jenis kanker dan dapat berguna untuk membedakan lesi tulang jinak dan ganas. Perkiraan sensitivitas 18FDG-PET untuk mendeteksi kisaran metastasis tulang dari $62 \%$ hingga 100\%, dan spesifisitas dari 96\% hingga 100\% (evidence level II-III). Pada satu studi prospektif dari 57 pasien dengan kanker payudara metastatik, 18FDG-PET dijumpai lebih banyak temuan negatif palsu untuk metastasis tulang daripada untuk metastasis non-osseous karena serapan 18FDG yang rendah oleh tulang (Minamimoto et al., 2015). Temuan positif palsu, di sisi lain, adalah hasil dari penyerapan 18FDG oleh otot yang jauh lebih tinggi, jaringan meradang, pembuluh besar, dan usus. Dalam studi lain dari 23 pasien dengan kanker payudara, 18FDG-PET lebih sensitif untuk mendeteksi osteolitik metastasis tetapi kurang sensitif untuk mendeteksi metastasis osteoblastik. Untuk mendeteksi osteolitik murni atau metastasis sumsum tulang belakang, 18FDG-PET mungkin lebih sensitif daripada sidik tulang planar. Saat ini, sidik tulang planar lebih menguntungkan daripada PET sebagai modalitas skrining seluruh tubuh untuk mendeteksi metastasis tulang dari kanker payudara karena biayanya yang rendah (Cook et al., 2016).

PET telah menunjukkan bahwa dapat digunakan untuk memonitor respons tumor payudara primer dan tumor nonoseus lainnya pengobatan. "Flare" yang terjadi dan diamati pada PET setelah hormonal terapi untuk lesi osseous dan nonosseous telah dianggap sebagai indikator awal respons terapi hormonal. Namun, peran klinis untuk PET dalam pemantauan respons metastasis tulang tetap tidak jelas saat ini dikarenakan kemoterapi yang bersamaan dengan sitokin (misalnya, 
faktor perangsang koloni granulosit) dapat menyebabkan peningkatan penyerapan FDG oleh sumsum tulang hiperplastik, yang bisa sulit dibedakan dari keterlibatan sumsum yang difus oleh tumor (Costelloe et al., 2009).

\section{Algoritme}

Beberapa literatur merekomendasikan pedoman penggunaan modalitas pencitraan untuk mendeteksi metastasis tulang (Cook et al., 2016). Dalam tinjauan ditemukan beberapa variasi substansial dalam memperkirakan sensitivitas dan spesifitas masing-masing teknik pencitraan, terutama karena referensi standar berbeda diantara studi yang dilakukan seperti yang terlihat pada gambar 8 (Ooe et al., 2013).

Pilihan pertama untuk skrining metastasis tulang adalah menggunakan sidik tulang planar seperti yang telihat pada gambar 9. Namun metode ini hanya menunjukkan metabolisme tulang. Studi pencitraan lain mungkin diperlukan untuk diagnosis yang akurat (radiografi, CT atau MRI). Jika terdapat gejala fokal, pencitraan anatomi harus digunakan terlebih dahulu untuk menvisualisasikan daerah yang sakit dan menilai integritas struktural tulang.

CT dan MRI dapat menggambarkan perubahan anatomi lebih detail daripada sidik tulang planar. MRI lebih disukai daripada CT untuk menilai metastasis tulang dikarenakan resolusi kontras jaringan lunak yang sangat baik, yang memungkinkan visualisasi yang lebih baik pada sumsum tulang dan jaringan lunak yang berdekatan (Costelloe et al., 2009).

CT menggambarkan korteks dan dapat membantu menbedakan karakteristik kalsifikasi abnormal. CT lebih dipilih dibandingkan MRI untuk menilai metastasis pada tulang rusuk. Jika MRI dan CT tidak dapat mendeteksi penyakit dan kecurigaan klinis metastasis tulang yang menetap atau perbaikan, maka direkomendasikan penggunaan PET/CT.

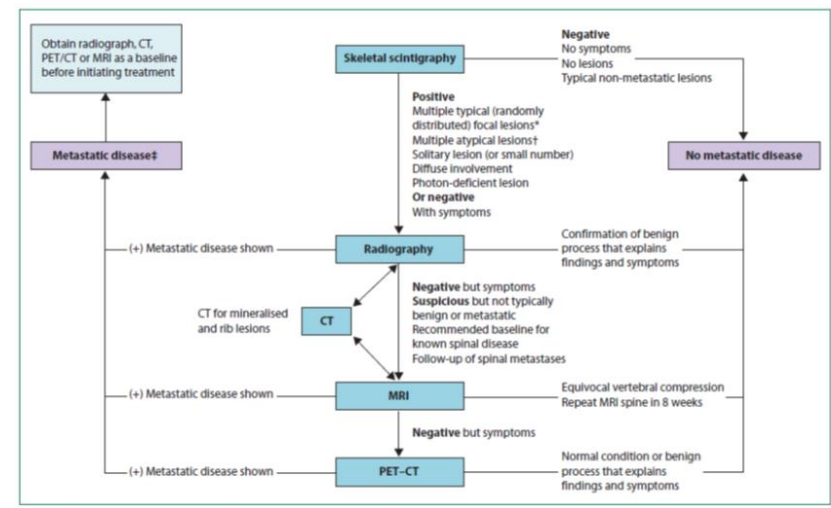

Gambar 9

Algoritma dari pencitraan untuk mendeteksi metastasis tulang

Pemantauan gejala pasien dan beban kanker selama pengobatan kanker payudara metastasis penting untuk menentukan apakah pengobatan memberikan manfaat dan 
bahwa pasien tidak memiliki toksisitas dari terapi yang tidak efektif (Haddad et al., 2019).

Komponen pemantauan meliputi penilaian berkala dari berbagai kombinasi gejala, pemeriksaan fisik, tes laboratorium rutin, pencitraan, dan biomarker darah jika perlu. Hasil pemantauan diklasifikasikan sebagai respons / tanggapan lanjutan terhadap pengobatan, status penyakit, ataupun perkembangan penyakit. Dokter biasanya harus menilai dan menyeimbangkan berbagai bentuk informasi untuk membuat keputusan mengenai apakah penyakit dapat disembuhkan dan toksisitas pengobatan dapat diterima (Haddad et al., 2019).

Bukti nyata dari perkembangan penyakit oleh satu atau lebih dari faktor-faktor ini diperlukan untuk menetapkan perkembangan penyakit, baik karena terapi yang tidak efektif atau resistensi yang didapat dari penyakit terhadap terapi yang diterapkan. Perkembangan penyakit dapat diidentifikasi melalui bukti pertumbuhan atau memburuknya penyakit di lokasi penyakit yang diketahui sebelumnya dan / atau terjadinya tempat baru penyakit metastasis (Hamaoka et al., 2004).

Frekuensi untuk pemeriksaan berulang untuk metastasis tulang belum ditentukan secara pasti, dan terutama didasarkan pada strategi pemantauan yang digunakan dalam uji klinis kanker payudara. Frekuensi pemantauan harus menyeimbangkan kebutuhan untuk mendeteksi penyakit progresif, menghindari toksisitas yang tidak perlu dari setiap pemanfaatan sumber daya terapi yang tidak efektif dan biaya penentuan. Tabel berikut adalah untuk memberikan panduan dan harus dimodifikasi untuk masing-masing pasien berdasarkan penyebaran penyakit, biologi penyakit dan rejimen pengobatan (Haddad et al., 2019). Penilaian kembali aktivitas penyakit harus dilakukan pada pasien dengan tanda atau gejala penyakit yang baru atau memburuk, terlepas dari interval waktu dari penelitian sebelumnya (tabel pada gambar 10).

\begin{tabular}{|c|c|c|c|c|}
\hline \multicolumn{5}{|c|}{ Suggested intervals of follow-up for patients with metastatic disease ${ }^{2}$} \\
\hline & $\begin{array}{l}\text { Baseline prior to new } \\
\text { therapy }\end{array}$ & Chemotherapy & Endocrine therapy & $\begin{array}{l}\text { Restaging if concern for } \\
\text { progression of disease }\end{array}$ \\
\hline Symptom assessment & Yes & Prior to each cycle & Every $1-3$ months & Yes \\
\hline Physical examination & Yes & Prior to each cycle & Every $1-3$ months & Yes \\
\hline Performance status & Yes & Prior to each cycle & Every $1-3$ months & Yes \\
\hline Weight & Yes & Prior to each cycle & Every $1-3$ months & Yes \\
\hline LFTs, CBC & Yes & Prior to each cycle & Every $1-3$ months & Yes \\
\hline $\begin{array}{l}\text { CT } \\
\text { chestrabd/pelvis with } \\
\text { contrast }\end{array}$ & Yes & Every 2-4 cycles & Every 2-6 months & Yes \\
\hline Bone scan & Yes & Every 4 cycles & Every 4-6 months & Yes \\
\hline PET/CT & Optional & Optional & Optional & Optional \\
\hline Tumor markers & Optional & Optional & Optional & Optional \\
\hline
\end{tabular}

Gambar 10

Tabel waktu pemeriksaan

\section{Kesimpulan}

Metatasis tulang pada pasien kanker payudara sangat sering dan dapat ditemukan di berbagai tempat terutama sternum, tulang rusuk, tulang belakang, tulang panggul, atau ekstremitas. Pola penyebaran metastasis adalah salah satu faktor penting dalam menentukan preferensi metastasis spesifik lokasi. 
Beberapa variasi estimasi yang substansial untuk sensitivitas dan spesifisitas masing-masing pencitraan modalitas, sebagian besar karena dasar untuk pengukuran sensitivitas dan spesifisitas berbeda dari setiap penelitian.

Banyak penelitian deskriptif menyarankan, pilihan pertama untuk penyaringan harus menggunakan sidik tulang, namun, sidik tulang sering perlu diikuti oleh modalitas lain ntuk diagnosis yang akurat karena sidik tulang hanya mencerminkan metabolisme tulang. Beberapa literatur menyatakan penggunaan rutin PET atau PET/CT untuk skrining tidak diperlukan, namun dimasa depan diharapkan dapat membawa perbaikan dalam sensitivitas dan spesifisitas dan pengurangan biaya dalam penggunaan teknologi ini. Pada saat ini, penggunaan kombinasi modalitas pencitraan, secara tepat urutan, untuk mendeteksi metastasis tulang tetap menjadi strategi manajemen yang paling efektif.

\section{BIBLIOGRAFI}

Bray, Freddie, Ferlay, Jacques, Soerjomataram, Isabelle, Siegel, Rebecca L., Torre, Lindsey A., \& Jemal, Ahmedin. (2018). Global cancer statistics 2018: GLOBOCAN estimates of incidence and mortality worldwide for 36 cancers in 185 countries. CA: A Cancer Journal for Clinicians, 68(6), 394-424.

Cook, Gary J. R., Azad, Gurdip K., \& Goh, Vicky. (2016). Imaging bone metastases in breast cancer: staging and response assessment. Journal of Nuclear Medicine, 57(Supplement 1), 27S-33S. Google Scholar

Costelloe, Colleen M., Rohren, Eric M., Madewell, John E., Hamaoka, Tsuyoshi, Theriault, Richard L., Yu, Tse Kuan, Lewis, Valerae O., Ma, Jingfei, Stafford, R. Jason, \& Tari, Ana M. (2009). Imaging bone metastases in breast cancer: techniques and recommendations for diagnosis. The Lancet Oncology, 10(6), 606614. Google Scholar

Dunnwald, Lisa K., Rossing, Mary Anne, \& Li, Christopher I. (2007). Hormone receptor status, tumor characteristics, and prognosis: a prospective cohort of breast cancer patients. Breast Cancer Research, 9(1), 1-10. Google Scholar

Haddad, R. I., Bischoff, L., Busaidy, N. L., Dickson, P., Duh, Q. Y., \& Ehya, H. (2019). NCCN Clinical Practice Guidelines in Oncology (NCCN Guidelines) for thyroid carcinoma, version 2.2019. Google Scholar

Hamaoka, Tsuyoshi, Madewell, John E., Podoloff, Donald A., Hortobagyi, Gabriel N., \& Ueno, Naoto T. (2004). Bone imaging in metastatic breast cancer. Journal of Clinical Oncology, 22(14), 2942-2953. Google Scholar

Hilton, J. F., Amir, E., Hopkins, S., Nabavi, M., DiPrimio, G., Sheikh, A., Done, S. J., Gianfelice, D., Kanji, F., \& Dent, S. (2011). Acquisition of metastatic tissue from patients with bone metastases from breast cancer. Breast Cancer Research and Treatment, 129(3), 761-765. Google Scholar 
Houssami, N., \& Costelloe, C. M. (2012). Imaging bone metastases in breast cancer: evidence on comparative test accuracy. Annals of Oncology, 23(4), 834-843. Google Scholar

Jamnasi, Juli, Gondhowiardjo, Soehartati Argadikoesoema, Djoerban, Zubairi, Siregar, Nurjati C., Poetiray, Evert D. C., \& Tunggono, Anna Puspita. (2016). Faktor Risiko Terjadinya Metastasis Jauh pada Pasien Kanker Payudara. Radioterapi \& Onkologi Indonesia, 7(2), 55-59. Google Scholar

Ju, Derek G., Yurter, Alp, Gokaslan, Ziya L., \& Sciubba, Daniel M. (2014). Diagnosis and surgical management of breast cancer metastatic to the spine. World Journal of Clinical Oncology, 5(3), 263. Google Scholar

Kemenkes, R. (2019). Laporan Nasional Riskesdas 2018. Badan Penelitian Dan Pengembangan Kesehatan. Google Scholar

Kozlow, Wende, \& Guise, Theresa A. (2005). Breast cancer metastasis to bone: mechanisms of osteolysis and implications for therapy. Journal of Mammary Gland Biology and Neoplasia, 10(2), 169-180. Google Scholar

Li, Qin, Chen, Zhiqiang, Zhao, Yansheng, Li, Xiuqing, Pan, Hong, Xia, Tiansong, Chen, Lin, Xu, Zhaoqiang, Zhou, Wenbin, \& Liu, Xiaoan. (2015). Risk of metastasis among rib abnormalities on bone scans in breast cancer patients. Scientific Reports, 5(1), 1-6. Google Scholar

Lien, Che Hui, Wen, Miin Jye, Huang, Li Ching, \& Wu, Kuo Lung. (2015). Online hotel booking: The effects of brand image, price, trust and value on purchase intentions. Asia Pacific Management Review, 20(4), 210-218. Google Scholar

Minamimoto, Ryogo, Loening, Andreas, Jamali, Mehran, Barkhodari, Amir, Mosci, Camila, Jackson, Tatianie, Obara, Piotr, Taviani, Valentina, Gambhir, Sanjiv Sam, \& Vasanawala, Shreyas. (2015). Prospective comparison of 99mTc-MDP scintigraphy, combined 18F-NaF and 18F-FDG PET/CT, and whole-body MRI in patients with breast and prostate cancer. Journal of Nuclear Medicine, 56(12), 1862-1868. Google Scholar

Nadji, Mehrdad, Gomez-Fernandez, Carmen, Ganjei-Azar, Parvin, \& Morales, Azorides R. (2005). Immunohistochemistry of estrogen and progesterone receptors reconsidered: experience with 5,993 breast cancers. American Journal of Clinical Pathology, 123(1), 21-27. Google Scholar

Ooe, Asako, Takahara, Sachiko, Sumiyoshi, Kazuhiro, Yamamoto, Hitoshi, Kawai, Jun, \& Shiba, Eiichi. (2013). Relationship between intrinsic subtypes and tumor responses to neoadjuvant chemotherapy in patients with locally advanced breast cancer. Breast Disease, 34(1), 9-17. Google Scholar

Parkes, Amanda, Clifton, Katherine, Al-Awadhi, Aydah, Oke, Oluchi, Warneke, Carla L., Litton, Jennifer K., \& Hortobagyi, Gabriel N. (2018). Characterization of bone 
Esther Devina Panjaitan, Hendra Budiawan

only metastasis patients with respect to tumor subtypes. NPJ Breast Cancer, 4(1), 1-7. Google Scholar

Pulido, Catarina, Vendrell, Inês, Ferreira, Arlindo R., Casimiro, Sandra, Mansinho, André, Alho, Irina, \& Costa, Luís. (2017). Bone metastasis risk factors in breast cancer. Ecancermedicalscience, 11. Google Scholar

Roodman, G. David. (2004). Mechanisms of bone metastasis. New England Journal of Medicine, 350(16), 1655-1664. Google Scholar

Zhong, G. X., Wu, Z. Y., Zhu, X., \& Lin, J. H. (2015). The Molecule Mechanisms of Bone Metastasis in Breast Cancer. J Orthop Oncol, 1(102), 2. Google Scholar

\section{Copyright holder:}

Esther Devina Panjaitan, Hendra Budiawan (2021)

\section{First publication right:}

Syntax Idea

This article is licensed under: 